\title{
Mobile Display Advertising: Perilaku Niat Pembelian Konsumen pada High Involvement vs Low Involvement Product
}

\author{
Jiwangga Hadi Nata ${ }^{1}$, Aries Kurniawan ${ }^{2 *}$ \\ 1,2 Universitas Muhammadiyah Gresik \\ 1jiwangga.edpunair@gmail.com, 2ariesaja@umg.ac.id \\ *Penulis korespondensi
}

\begin{abstract}
This study uses the theory of Stimulus-Organism-Response (S-O-R) using a quantitative approach. Sampling using non-probability sampling method, using purposive sampling technique. Respondents in this study were 200 respondents in the purchase intention category in the High Involvement product and also 200 in the Low Involvement product category. The analysis technique used in this study is Partial Least Square (PLS). The results showed that browsing activities on Instagram for both the High and Low Involvement categories of the product had a positive influence on flow conditions, online trust, and purchase intentions. Then online trust in an account on Instagram has a positive influence on flow conditions. Likewise, the flow condition variable and online trust also have an influence on the purchase intention of the latest items on Instagram. There is no difference in consumer behavior towards purchase intentions in the online domain between High and Low Involvement products.
\end{abstract}

Keywords: browsing activity, flow, online trust, purchase intention, Instagram

\begin{abstract}
Abstrak
Penelitian ini menggunakan teori Stimulus-Organism-Response (S-O-R) dengan menggunakan pendekatan kuantitatif. Pengambilan sampel dengan menggunakan metode non-probability sampling, menggunakan tehnik purposive sampling. Responden dalam penelitian ini sebanyak 200 responden untuk kategori niat pembelian pada High Involvement produk dan juga 200 orang pada kategori Low Involvement produk. Teknik Analisa yang digunakan dalam penelitian ini adalah Partial Least Square (PLS). Hasil penelitian menunjukkan bahwa aktivitas browsing pada Instagram baik untuk kategori High maupun Low Involvement produk memiliki pengaruh positif terhadap kondisi flow, kepercayaan online, dan niat pembelian. Kemudian kepercayaan online pada akun di Instagram memiliki pengaruh positif terhadap kondisi flow. Demikian juga dengan variabel kondisi flow dan kepercayaan online juga memiliki pengaruh terhadap niat pembelian barang-barang terbaru di Instagram. Tidak ada perbedaan perilaku konsumen terhadap niat pembelian di ranah online antara High maupun Low Involvement produk.
\end{abstract}

Kata kunci: aktivitas browsing, flow, kepercayaan online, niat pembelian, Instagram 


\section{PENDAHULUAN}

Perkembangan teknologi informasi telah banyak merubah perilaku konsumen, dimana saat ini konsumen Indonesia banyak menggunakan internet sebagai media berbelanja. Bagi masyarakat Indonesia, berbelanja online merupakan pilihan yang cerdas karena dapat menghemat uang dan waktu, memberikan keleluasaan, serta mendapatkan banyak informasi ketika akan membuat suatu keputusan tanpa merasa ada paksaan untuk melakukan pembelian (Rahayu, 2014). Hasil survei dari Monitor Consumen E-Commerce tahun 2010 menunjukkan bahwa masyarakat Indonesia menghabiskan rata-rata $24 \%$ dari penghasilan mereka untuk berbelanja online. Hal ini didukung dengan banyaknya aplikasi mobile commerce dan juga perkembangan platform sosial media sebagai media komunikasi dan promosi untuk menjual barang dan jasa melalui internet dengan memanfaatkan smartphone yang lebih dikenal dengan m-commerce. Masyarakat Indonesia gemar berbelanja melalui mobile-phone dengan presentase 57\% untuk berbelanja (Prihatna, 2016). Pasar E-commerce di Indonesia memiliki potensi yang besar, hal ini dilihat dari jumlah pengguna Internet di Indonesia mencapai 82 juta orang atau sekitar 30\% dari total penduduk, dengan nilai pasar E-Commerce diperkirakan mencapai Rp. 94,5 Triliun pada tahun 2013 dan diperkirakan meningkat pesat 30\% menjadi 295 Triliun pada tahun 2016 (Survey IdEA dan TNS, 2015).

Penjualan dari seluruh ritel e-commerce Indonesia diperkirakan mencapai US\$ 8,59 miliar atau sekitar Rp 117,7 triliun pada 2018. Jumlah tersebut, menurut data Statista bakal meningkat menjadi US\$ 16,5 miliar pada 2022 atau naik hampir dua kali lipat dari tahun ini. Sementara pembeli digital Indonesia diperkirakan mencapai 31,6 juta pembeli pada 2018, dengan penetrasi sekitar 11,8\% dari total populasi. Jumlah tersebut diproyeksikan akan meningkat menjadi 43,9 juta pembeli pada 2022 dengan penetrasi 15,7\% dari jumlah penduduk Indonesia.

Penjualan e-commerce Indonesia merupakan yang terbesar di Kawasan Asia Tenggara. Berdasarka proyeksi dari Statista, penjualan ritel perdagangan digital Indonesia mencapa US\$ 5,29 miliar. Angka tersebut merupakan yang tertinggi dibandingkan penjualan ritel e-commerce negara Asean lainnya seperti Thailang sebesar US\$ 2,89 miliar, Singapura US\$ 2,13 miliar, Malaysia US\$1,97 miliar, dan Vietnam US\$1,71 miliar. Penjualan total e-commerce Indonesia diperkirakan akan mencapai US\$ 46 miliar atau sekitar 8\% dari penjualan ritel pada tahun 2025. Pangsa pasar e-commerce domestik tersebut setara dengan 52\% dari e-commerce enam negara Asia Tenggara yaitu Singapura, Malaysia, Thailand, Filipina, Vietnam, Laos. (Katadata.co.id:2017).

Selain melalui beberapa situs E-Commerce, Sosial media merupakan suatu media dimana konsumen dapat saling berbagi tulisan, foto, dan video informasi termasuk juga berinteraksi dengan perusahaan.Dengan sosial media, pemasar dapat membangun komunikasi dengan konsumen dan dapat meningkatkan aktivitas komunikasinya (Kotler dan Keller, 2015). Salah satu sosial media yang mempunyai karakteristik unik adalah Instagram. Instagram pada mulanya dikembangkan sebagai wadah untuk berbagi foto dan video kepada sesama penggunanya. Pada perkembangannya, instagram menjadi salah satu sosial media yang potensial untuk aktivitas pemasaran (Nuttamon et al., 2015).

Niat pembelian adalah proses yang ada diantara evaluasi alternatif dan keputusan pembelian dalam model pengambilan keputusan pembelian, yaitu tahap kecenderungan 
seseorang untuk bertindak sebelum benar-benar memutuskan untuk melakukan pembelian (Harun, 2003). Proses pencarian informasi melalui aktivitas browsing berasosiasi positif terhadap sikap atau perilaku terhadap suatu brand maupun suatu website (Mathwick dan Rigdon, 2004). Di instagram sendiri, pengguna instagram sendiri mencari dan juga terpapar informasi mengenai produk dari akun yang mereka ikuti yang dapat mempengaruhi perilaku pembelian online mereka. Informasi yang mereka dapatkan membuat pelanggan mempunyai image tertentu terhadap suatu produk.

Dalam mencari informasi melalui aktivitas browsing, pelanggan sebagai pengguna instagram kadangkala merasa hanyut dengan perasaan menyenangkan dalam aktivitas tersebut, hingga lupa waktu dan kehilangan konsentrasi pada lingkungan sekitar yang didefinisikan bahwa pelanggan memasuki kondisi flow (Csikszentmihalyi, 1977). Informasi yang didapat kadangkala membuat pelanggan langsung percaya terhadap komunikasi pemasaran yang dilakukan produsen, namun tak jarang juga membuat mereka raguragu sehingga mereka memerlukan banyak pembanding mengenai suatu produk dari beberapa produsen. Trust pada media sosial online dapat disebut online trust, dimana perlu dibangun dengan memanfaatkan media komunikasi yang efektif antara perusahaan atau pemasar dengan pelanggan. Trust bisa dibangun melalui komunikasi pemasaran yang aktif, dimana pelanggan terpapar komunikasi pemasaran melalui media komunikasi yang mereka ikuti yaitu Instagram dengan mendesai suatu komunikasi yang efektif dan membuat terciptanya engagement pelanggan dengan produk sebagai hasil yang didapat dari aktivitas browsing dan informasi yang mereka peroleh. Low involvement product adalah produk yang mempunyai resiko yang rendah bagi konsumen saat membeli produk tersebut. Contoh low involvement product yaitu produk-produk yang dipakai sehari-hari dan konsumen tidak perlu berfikir panjang untuk membeli produk tersebut (John, 1984). Sedangkan high involvement product adalah produk yang memiliki resiko tinggi untuk konsumen dan mereka butuh waktu untuk berpikir panjang sebelum melakukan pembelian (John, 1984). Produk involve adalah bagaimana konsumen terlibat dalam mendapatkan suatu produk. Keterlibatan disini adalah keterlibatan menyangkut bagaimana mereka mencari informasi dan proses pertimbangan yang mereka lakukan sebelum akhirnya mereka mengambil suatu keputusan pembelian. Semakin tinggi tingkat keterlibatan konsumen, maka semakin banyak pertimbangan dan fikiran untuk melakukan suatu keputusan pembelian terhadap suatu barang.

Terdapat lebih dari 22 juta pengguna Instagram Indonesia rata-rata mengakses Instagram 21 menit per harinya. Berdasarkan data internal Instagram pada tahun 2015, hampir setengah dari total pengguna di Instagram mengikuti akun bisnis. Kemudian hampir $60 \%$ nya mengetahui produk tertentu ataupun layanan baru dari Instagram dan 34\% telah mengunjungi website untuk informasi lebih lanjut (Fajrina, 2016). Hal ini menegaskan bahwa hampir semua konsumen merasakan suatu pengalaman dalam aktivitas browsing di Instagram dan mereka melakukan aktivitas browsing dengan tujuan yang berbeda namun dapat dikerucutkan bahwa mereka melakukan aktivitas browsing untuk mencari informasi tentang suatu produk.

Proses pencarian informasi berasosiasi positif terhadap sikap atau perilaku terhadap suatu brand maupun suatu website (Mathwick \& Rigdon, 2004), hal ini secara tidak langsung 
menuntut pemasar agar dapat mendesain website yang atraktif sehingga dapat menarik perhatian pemasar dan dapat menyediakan informasi yang jelas sehingga tujuan pemasaran untuk merubah perilaku yang positif terhadap merek dapat tercapai. Jutaan orang di seluruh dunia menggunakan internet untuk mencari informasi tentang suatu produk, dan kemudian melakukan pembelian online setelahnya (Carboni, 2015).

Jakpat yang merupakan leader dari Research Market di Indonesia melakukan survey pada tahun 2016, memberikan hasil bahwa 49\% pengguna melakukan pembelian produk dari merek yang mereka ikuti di akun Instagram mereka, 55\% mengetahui brand dan produk terbaru perusahaan dari Instagram, 43\% mengunjungi situs sebuah merek setelah melihat aktivitas merek tersebut di Instagram (Rizky, 2016). Hal ini menegaskan bahwa Instagram menjadi revolusi baru menjadi media pemasaran yang efektif dalam 5 tahun terakhir ini. Instagram merilis bahwa ada sebanyak 95 juta dan video yang di publikasikan dengan 4,2 miliar likes per hari, hal ini menjadikan Instagram menjadi salah satu media sosial yang potensial dalam mengiklankan produk.

\section{METODE}

Pendekatan yang digunakan di dalam penelitian ini adalah pendekatan kuantitatif dan menitikberatkan pada pengujian hipotesis dengan menggunakan data-data primer yang terukur dan menggunakan metode analisis statistik sehingga dapat menghasilkan kesimpulan yang dapat digeneralisasi. Asumsi yang digunakan dalam penelitian ini berupa variabel-variabel yang dapat diukur dan memiliki hubungan kausalitas (Burns dan Bush, 2014).

Metode pengambilan sampel di dalam penelitian ini adalah dengan menggunakan metode non-probability sampling, dan teknik yang digunakan adalah purposive sampling, di dalam teknik ini sampel yang ditarik adalah sampel tertentu yang diambil oleh peneliti dengan tidak secara acak, tapi ditentukan sendiri oleh peneliti dengan penilaian bahwa sampel yang diambil tersebut sesuai dengan tujuan atau masalah penelitian.

Model struktural seringkali membutuhkan jumlah sampel yang relatif besar jika dibandingkan dengan alat analisis multivariat yang lainnya, jumlah sampel yang baik untuk analisis yang menggunakan model struktural adalah pada kisaran 100-400 (Hair et al., 2010). Dalam penelitian ini ditentukan bahwa sampel minimum adalah 200 sampel untuk responden kategodi High Involvement produk dan 200 responden Low Involvement produk.

Alat analisis yang digunakan dalam penelitian ini adalah Varian-Based SEM (VB-SEM) atau yang lebih dikenal sebagai Partial Least Square (PLS). Sebelum melakukan uji hipotesis perlu dilakukan beberapa rangkaian uji, yang pertama adalah uji validitas dan reliabilitas yang digunakan untuk menguji apakah data yang diperoleh sudah valid dan reliabel sehingga dapat diproses lebih lanjut, kemudian yang kedua adalah uji kebaikan model (model fit) yang digunakan untuk menguji ketepatan dari model yang dipakai. Apabila kedua uji tersebut telah terpenuhi maka langkah terakhir adalah melakukan uji hipotesis. Alat analisis ini akan dijalankan dengan bantuan software yakni SmartPLS. 
Gambar 1. Model Konseptual Penelitian

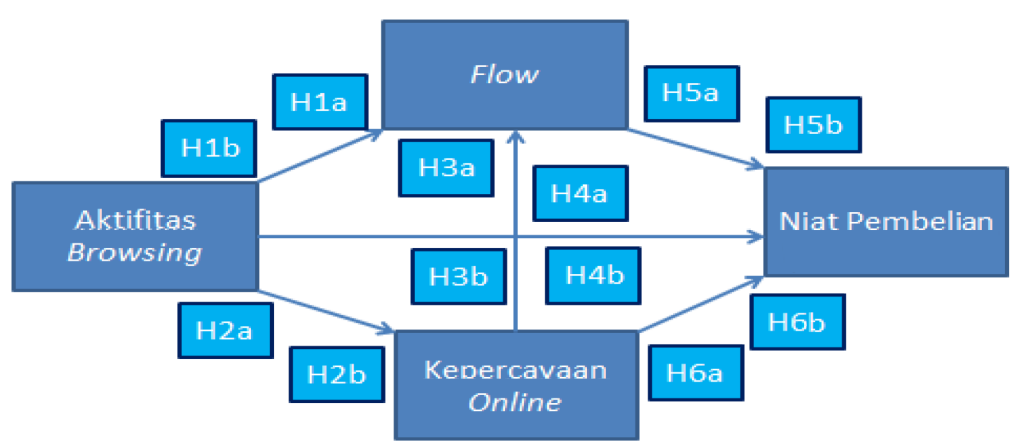

Berdasarkan pada rumusan masalah, tujuan penelitian, hasil penelitian terdahulu, dan landasan teori yang digunakan. Gambar 1 menunjukkan hubungan kausalitas antara variabel independen terhadap niat beli. Didalam model yang direncanakan diatas, dapat dilihat bahwa online trust dan flow memiliki peran sentral dan memediasi variabel aktivitas browsing terhadap niat pembelian barang-barang terbaru di instagram.

\section{HASIL DAN PEMBAHASAN}

Tabel 1. Uji Reliabilitas pada High Involvement Product

\begin{tabular}{|c|c|c|c|c|}
\hline & Aktifitas Browsing & Flow & Kepercayaan Online & Niat Pembelian \\
\hline Browsing1 & 0.884333 & & & \\
\hline Browsing2 & 0.893440 & & & \\
\hline Browsing3 & 0.888276 & & & \\
\hline Flow1 & & 0.848088 & & \\
\hline Flow2 & & 0.872195 & & \\
\hline Flow3 & & 0.907291 & & \\
\hline Flow4 & & 0.876050 & & \\
\hline Flow5 & & 0.865744 & & \\
\hline Intention1 & & & & 0.896222 \\
\hline Intention2 & & & & 0.876481 \\
\hline Intention3 & & & & 0.906119 \\
\hline Trust1 & & & 0.872470 & \\
\hline Trust2 & & & 0.850696 & \\
\hline Trust3 & & & 0.871049 & \\
\hline Trust4 & & & 0.872861 & \\
\hline Trust5 & & & 0.880640 & \\
\hline
\end{tabular}

Uji reliabilitas digunakan untuk mengukur konsistensi konstruk/variabel penelitian. Suatu variabel dikatakan reliable (handal) jika jawaban responden terhadap pertanyaan konsisten atau stabil dari waktu ke waktu. Instrumen yang reliabel berarti instrumen tersebut bila digunakan beberapa kali untuk mengukur suatu obyek yang sama, akan menghasilkan daya yang sama (Sugiyono \& Susanto, 2015). Tingkat reliabilitas suatu konstruk/ variabel 
penelitian dapat dilihat dari hasil statistik cronbach alpha $(\alpha)$. Hasil perhitungan reliabilitas dapat dilihat pada Tabel 1

Tabel 2. Cronbachs Alpha

\begin{tabular}{cc}
\hline & Cronbachs Alpha \\
\hline Aktifitas Browsing & 0.866901 \\
Flow & 0.922651 \\
Kepercayaan Online & 0.919367 \\
Niat Pembelian & 0.873026 \\
\hline
\end{tabular}

Dilihat dari Tabel 1 terlihat bahwa seluruh indikator telah memiliki nilai loadings diatas 0,5. Artinya seluruh indikator didalam penelitian ini reliabel. Pada Tabel 2 terlihat seluruh nilai Cronbachs Alpha masing-masing variabel berada diatas 0,5. Hal ini menunjukkan bahwa seluruh indikator adalah reliabel.

Tabel 3. Composite Reliability

\begin{tabular}{cc}
\hline & Composite Reliability \\
\hline Aktifitas Browsing & 0.918500 \\
Flow & 0.941796 \\
Kepercayaan Online & 0.939420 \\
Niat Pembelian & 0.921949 \\
\hline
\end{tabular}

Pada Tabel 3 terlihat seluruh nilai Composite Reliability masing-masing variabel berada diatas 0,5. Hal ini menunjukkan bahwa seluruh indikator adalah Reliabel. Dilihat dari Tabel 4 terlihat bahwa seluruh indikator telah memiliki nilai loadings diatas 0,5 . Artinya seluruh indikator didalam penelitian ini reliabel.

Tabel 4. Uji Reliabilitas pada Low Involvement Produk

\begin{tabular}{|c|c|c|c|c|}
\hline & Aktivitas Browsing & Flow & Kepercayaan Online & Niat Pembelian \\
\hline Browsing1 & 0.885748 & & & \\
\hline Browsing2 & 0.891426 & & & \\
\hline Browsing3 & 0.877856 & & & \\
\hline Flow1 & & 0.843228 & & \\
\hline Flow2 & & 0.868307 & & \\
\hline Flow3 & & 0.896567 & & \\
\hline Flow4 & & 0.879019 & & \\
\hline Flow5 & & 0.858895 & & \\
\hline Intention1 & & & & 0.885695 \\
\hline Intention2 & & & & 0.860082 \\
\hline Intention3 & & & & 0.896458 \\
\hline Trust1 & & & 0.886244 & \\
\hline Trust2 & & & 0.859216 & \\
\hline Trust3 & & & 0.866615 & \\
\hline Trust4 & & & 0.880981 & \\
\hline Trust5 & & & 0.860337 & \\
\hline
\end{tabular}


Pada Tabel 5 terlihat seluruh nilai Cronbachs Alpha masing-masing variabel berada diatas 0,5. Hal ini menunjukkan bahwa seluruh indikator adalah Reliabel. Pada Tabel 6 terlihat seluruh nilai Composite Reliability masing-masing variabel berada diatas 0,5. Hal ini menunjukkan bahwa seluruh indikator adalah Reliabel.

Tabel 5. Cronbachs Alpha

\begin{tabular}{cc}
\hline & Cronbachs Alpha \\
\hline Aktivitas Browsing & 0.861633 \\
Flow & 0.919131 \\
Kepercayaan Online & 0.920224 \\
Niat Pembelian & 0.855637 \\
\hline
\end{tabular}

Di dalam PLS terdapat 2 pengujian untuk melihat apakah konstruk didalam model telah memiliki tingkat validitas yang baik yakni validitas konvergen dan validitas diskriminan. Berdasar pada Kwong dan Wong (2013) validitas konvergen dapat dilihat dari output AVE. Suatu konstruk dikatakan memiliki convergent validity yang baik adalah apabila nilai AVE melebihi 0,50.

Tabel 6. Composite Reliability

\begin{tabular}{cc}
\hline & Composite Reliability \\
\hline Aktivitas Browsing & 0.915554 \\
Flow & 0.939290 \\
Kepercayaan Online & 0.940033 \\
Niat Pembelian & 0.912176 \\
\hline
\end{tabular}

Evaluasi goodness of fit dilakukan dengan melihat skor R-square $\left(\mathrm{R}^{2}\right)$ pada variabel laten dependen untuk menilai vaiabilitas konstruk independen terhadap konstruk dependen. Berikut adalah hasil R-square model penelitian ini:

Tabel 7. R-Square High Involvement Produk

\begin{tabular}{cc}
\hline & R Square \\
\hline Aktifitas Browsing & \\
Flow & 0.871953 \\
Kepercayaan Online & 0.814604 \\
Niat Pembelian & 0.840322 \\
\hline
\end{tabular}

Berdasar pada Tabel 7 terlihat nilai R-Square seluruh variabel endogen dalam penelitian ini adalah diatas 0,7. Artinya model dalam penelitian ini dapat dinilai sangat baik.

Tabel 8. R-Square Low Involvement Produk

\begin{tabular}{cc}
\hline & R Square \\
\hline Aktivitas Browsing & \\
Flow & 0.862060 \\
Kepercayaan Online & 0.804991 \\
Niat Pembelian & 0.842823 \\
\hline
\end{tabular}


Berdasar pada Tabel 8 terlihat nilai R-Square seluruh variabel endogen dalam penelitian ini adalah diatas 0,7 . Artinya model dalam penelitian ini dapat dinilai sangat baik.

Pada PLS, koefisien parameter jalur diperoleh melalui bobot inner model dengan terlebih dahulu dicari T-statistik melalui prosedur bootstrap standart error. Menurut Kock (2015) di dalam PLS-SEM akan lebih baik untuk melihat titik cut-off berdasarkan pada pengujian 1 arah ataukah 2 arah. Dalam penelitian ini seluruh hipotesis sudah diprediksi memiliki satu arah yakni "positif" sehingga pengujian hipotesis akan baik jika menggunakan nilai cut-off pengujian satu arah (1 tailed $t$ test). Nilai cut-off 1 tailed $t$ test untuk pengujian hipotesis pada penelitian ini di dapatkan sebesar 1.65271 pada nilai $\alpha=5 \%$.

Tabel 9. Uji Hipotesis: High Involvement

\begin{tabular}{|c|c|c|c|c|c|}
\hline & $\begin{array}{l}\text { Original } \\
\text { Sample (O) }\end{array}$ & $\begin{array}{l}\text { Sample } \\
\text { Mean (M) }\end{array}$ & $\begin{array}{c}\text { Standard Deviation } \\
\text { (STDEV) }\end{array}$ & $\begin{array}{l}\text { Standard Error } \\
\text { (STERR) }\end{array}$ & $\begin{array}{l}\text { T Statistics } \\
\text { (|O/STERR|) }\end{array}$ \\
\hline $\begin{array}{c}\text { Aktifitas } \\
\text { Browsing }>\text { Flow }\end{array}$ & 0.424456 & 0.416536 & 0.060928 & 0.060928 & 6.966478 \\
\hline $\begin{array}{l}\text { Aktifitas Browsing -> } \\
\text { Kepercayaan Online }\end{array}$ & 0.902554 & 0.898780 & 0.020166 & 0.020166 & 44.757171 \\
\hline $\begin{array}{c}\text { Aktifitas Browsing -> } \\
\text { Niat Pembelian }\end{array}$ & 0.243464 & 0.242144 & 0.076945 & 0.076945 & 3.164128 \\
\hline Flow -> Niat Pembelian & 0.427777 & 0.421125 & 0.078712 & 0.078712 & 5.434738 \\
\hline $\begin{array}{c}\text { Kepercayaan Online -> } \\
\text { Flow }\end{array}$ & 0.532630 & 0.538788 & 0.057783 & 0.057783 & 9.217823 \\
\hline $\begin{array}{l}\text { Kepercayaan Online -> } \\
\text { Niat Pembelian }\end{array}$ & 0.273632 & 0.280614 & 0.084532 & 0.084532 & 3.237025 \\
\hline
\end{tabular}

Berdasarkan pada Tabel 9, terlihat bahwa nilai T-statistik hubungan antar variabel adalah diatas 0,05 , dan nilai koefisien (original sample) bernilai positif. Hal ini bermakna bahwa:

1. Aktifitas Browsing memiliki pengaruh positif terhadap Flow

2. Aktifitas Browsing memiliki pengaruh positif terhadap Kepercayaan Online

3. Aktifitas Browsing memiliki pengaruh positif terhadap Niat Pembelian

4. Flow memiliki pengaruh positif terhadap Niat Pembelian

5. Kepercayaan Online memiliki pengaruh positif terhadap Flow

6. Kepercayaan Online memiliki pengaruh positif terhadap Niat pembelian Pada produkproduk high involvement 
Tabel 10. Total Effects (Mean, STDEV, T-Values)

\begin{tabular}{cccccc}
\hline & $\begin{array}{c}\text { Original } \\
\text { Sample (O) }\end{array}$ & $\begin{array}{c}\text { Sample } \\
\text { Mean (M) }\end{array}$ & $\begin{array}{c}\text { Standard } \\
\text { Deviation (STDEV) }\end{array}$ & $\begin{array}{c}\text { Standard Error } \\
\text { (STERR) }\end{array}$ & $\begin{array}{c}\text { T Statistics } \\
\text { (|O/STERR|) }\end{array}$ \\
\hline $\begin{array}{c}\text { Aktifitas Browsing -> } \\
\text { Flow }\end{array}$ & 0.905183 & 0.900733 & 0.021571 & 0.021571 & 41.963682 \\
$\begin{array}{c}\text { Aktifitas Browsing -> } \\
\text { Kepercayaan Online }\end{array}$ & 0.902554 & 0.898780 & 0.020166 & 0.020166 & 44.757171 \\
$\begin{array}{c}\text { Aktifitas Browsing -> } \\
\text { Niat Pembelian }\end{array}$ & 0.877648 & 0.873817 & 0.023430 & 0.023430 & 37.458023 \\
$\begin{array}{c}\text { Flow -> Niat Pembelian } \\
\quad\end{array}$ & 0.427777 & 0.421125 & 0.078712 & 0.078712 & 5.434738 \\
$\begin{array}{c}\text { Kepercayaan Online -> } \\
\text { Flow }\end{array}$ & 0.532630 & 0.538788 & 0.057783 & 0.057783 & 9.217823 \\
$\begin{array}{c}\text { Kepercayaan Online -> } \\
\text { Niat Pembelian }\end{array}$ & 0.501479 & 0.507525 & 0.076361 & 0.076361 & 6.567232 \\
\hline
\end{tabular}

Berdasarkan Tabel 10 dapat diperoleh penjelasan bahwa:

1. Nilai t-statistik dari variabel aktivitas browsing terhadap flow sebesar 41.963682 Lebih dari 1.65271 yang artinya variabel aktivitas browsing memberikan dampak positif terhadap flow sehingga hipotesis ke-1 yang berbunyi "aktivitas browsing berpengaruh positif terhadap flow" dapat diterima.

2. Nilai t-statistik dari variabel aktivitas browsing terhadap kepercayaan online sebesar 44.757171lebih dari 1.65271 yang artinya variabel aktivitas browsing memberikan dampak positif terhadap kepercayaan online sehingga hipotesis ke-2 yang berbunyi "aktivitas browsing berpengaruh positif terhadap kepercayaan online" dapat diterima.

3. Nilai t-statistik dari variabel kepercayaan online terhadap flow sebesar 37.458023, nilai ini lebih dari 1.65271 yang artinya variabel kepercayaan online memberikan dampak positif terhadap flow sehingga hipotesis ke-3 yang berbunyi "kepecayaan online berpengaruh positif terhadap flow" dapat diterima.

4. Nilai t-statistik dari variabel aktivitas browsing terhadap niat pembelian sebesar 5.434738Lebih dari 1.65271 yang artinya variabel aktivitas browsing memberikan dampak positif terhadap niat beli sehingga hipotesis ke-4 yang berbunyi "aktivitas browsing berpengaruh positif terhadap kondisi niat pembelian" dapat diterima.

5. Nilai T-statistik dari variabel flow terhadap niat pembelian sebesar 9.217823lebih dari 1.65271 yang artinya variabel flow memberikan dampak terhadap niat beli sehingga hipotesis ke-5 yang berbunyi "flow berpengaruh positif terhadap niat pembelian" dapat diterima.

6. Nilai T-statistik dari variabel kepercayaan online terhadap niat pembelian sebesar 6.567232 Lebih dari 1.65271 yang artinya variabel kepercayaan online memberikan dampak positif terhadap niat beli sehingga hipotesis ke-6 yang berbunyi "kepercayaan online berpengaruh positif terhadap niat pembelian" dapat diterima. 
Tabel 11. Uji Hipotesis: Low Involvement

\begin{tabular}{cccccc}
\hline & $\begin{array}{c}\text { Original } \\
\text { Sample (O) }\end{array}$ & $\begin{array}{c}\text { Sample } \\
\text { Mean (M) }\end{array}$ & $\begin{array}{c}\text { Standard Deviation } \\
\text { (STDEV) }\end{array}$ & $\begin{array}{c}\text { Standard } \\
\text { Error (STERR) }\end{array}$ & $\begin{array}{c}\text { T Statistics } \\
(\mid \text { O/STERR|) }\end{array}$ \\
\hline $\begin{array}{c}\text { Aktivitas Browsing -> Flow } \\
\quad 0.412371\end{array}$ & 0.406705 & 0.062508 & 0.062508 & 6.597039 \\
$\begin{array}{c}\text { Aktivitas Browsing -> } \\
\text { Kepercayaan Online }\end{array}$ & 0.897213 & 0.893783 & 0.023473 & 0.023473 & 38.223738 \\
$\begin{array}{c}\text { Aktivitas Browsing -> } \\
\text { Niat Pembelian }\end{array}$ & 0.263166 & 0.268029 & 0.071964 & 0.071964 & 3.656890 \\
$\quad \begin{array}{l}\text { Flow -> Niat Pembelian } \\
\quad\end{array}$ & 0.392479 & 0.382158 & 0.076154 & 0.076154 & 5.153756 \\
$\begin{array}{c}\text { Kepercayaan Online -> Flow } \\
\text { Kepercayaan Online -> Niat }\end{array}$ & 0.540454 & 0.544196 & 0.059573 & 0.059573 & 9.072122 \\
$\quad$ Pembelian & 0.293319 & 0.298287 & 0.075683 & 0.075683 & 3.875614 \\
\hline
\end{tabular}

Berdasar pada Tabel 11, terlihat bahwa nilai T-statistik hubungan antar variabel adalah diatas 0,05 , dan nilai koefisien (original sample) bernilai positif. Hal ini bermakna bahwa:

1. Aktifitas Browsing memiliki pengaruh positif terhadap Flow

2. Aktifitas Browsing memiliki pengaruh positif terhadap Kepercayaan Online

3. Aktifitas Browsing memiliki pengaruh positif terhadap Niat Pembelian

4. Flow memiliki pengaruh positif terhadap Niat Pembelian

5. Kepercayaan Online memiliki pengaruh positif terhadap Flow

6. Kepercayaan Online memiliki pengaruh positif terhadap Niat pembelian pada produkproduk low involvement

Berdasarkan Tabel 12 diperoleh penjelasan bahwa:

1) Nilai T-statistik dari variabel aktivitas browsing terhadap flow sebesar 35.193116 Lebih dari 1.65271 (1-tailed $t$ test) yang artinya variabel aktivitas browsing memberikan dampak positif terhadap flow sehingga hipotesis ke-1 yang berbunyi "aktivitas browsing berpengaruh positif terhadap flow" dapat diterima.

2) Nilai T-statistik dari variabel aktivitas browsing terhadap kepercayaan online sebesar 38.223738 lebih dari 1.65271 (1-tailed t test) yang artinya variabel aktivitas browsing memberikan dampak positif terhadap kepercayaan online sehingga hipotesis ke-2 yang berbunyi "aktivitas browsing berpengaruh positif terhadap kepercayaan online" dapat diterima.

3) Nilai T-statistik dari variabel kepercayaan online terhadap flow sebesar 34.610899 Lebih dari 1.65271 (1-tailed t test) yang artinya variabel kepercayaan online memberikan dampak positif terhadap flow sehingga hipotesis ke-3 yang berbunyi "kepecayaan online berpengaruh positif terhadap flow" dapat diterima.

4) Nilai T-statistik dari variabel aktivitas browsing terhadap niat pembelian sebesar 5.153756 Lebih dari 1.65271 (1-tailed t test) yang artinya variabel aktivitas browsing memberikan dampak positif terhadap niat beli sehingga hipotesis ke-4 yang berbunyi "aktivitas browsing berpengaruh positif terhadap kondisi niat pembelian" dapat diterima. 
5) Nilai T-statistik dari variabel flow terhadap niat pembelian sebesar 9.072122 lebih dari 1.65271 (1-tailed $t$ test) yang artinya variabel flow memberikan dampak terhadap niat beli sehingga hipotesis ke-5 yang berbunyi "flow berpengaruh positif terhadap niat pembelian" dapat diterima.

6) Nilai T-statistik dari variabel kepercayaan online terhadap niat pembelian sebesar 7.321517 Lebih dari 1.65271 (1-tailed t test) yang artinya variabel kepercayaan online memberikan dampak positif terhadap niat beli sehingga hipotesis ke- 6 yang berbunyi "kepercayaan online berpengaruh positif terhadap niat pembelian" dapat diterima.

7) Dari hasil uji hipotesis terhadap High dan Low involvement produk diatas, dapat diketahui bahwa semua hipotesis dapat diterima.

Berdasarkan hasil pengolahan data yang dilakukan, diperoleh hasil bahwa terdapat pengaruh positif antara aktifitas browsing yang dilakukan pengguna Instagram terhadap kondisi flow di kedua kategori produk involvement yang terjadi pada diri konsumen. Hasil ini memberikan suatu pengetahuan bahwa ketika konsumen melakukan suatu aktifitas penjelajahan online sebagai pengguna media sosial Instagram, mereka akan mencari tahu dan mengumpulkan informasi dari akun yang mereka ikuti dengan cara melihat posting dan display barang di akun tersebut, melihat review dan komentar dari pengguna lain tentang barang tersebut hal ini akan mempengaruhi persepsi mereka dan berimbas pada perilaku pembelian mereka.

Berdasarkan hasil pengolahan data yang dilakukan, diperoleh hasil bahwa terdapat pengaruh positif antara aktivitas browsing terhadap kepercayaan online pada kedua kategori produk involvement. Aktifitas browsing yang kerapkali dikenal dengan penjelajahan online yang dilakukan konsumen Instagram pada akun yang mereka ikuti, bertujuan melakukan update terhadap posting barang terbaru pada akun tersebut. Aktifitas tersebut membuat konsumen memperoleh informasi yang disajikan oleh akun tersebut terhadap semua jenis barang yang mereka posting sehingga pemahaman konsumen terhadap barang yang dijual akan semakin dalam.

Tabel 12. Total Effects (Mean, STDEV, T-Values)

\begin{tabular}{cccccc}
\hline & $\begin{array}{c}\text { Original } \\
\text { Sample (O) }\end{array}$ & $\begin{array}{c}\text { Sample } \\
\text { Mean (M) }\end{array}$ & $\begin{array}{c}\text { Standard } \\
\text { eviation (STDEV) }\end{array}$ & $\begin{array}{c}\text { Standard Error } \\
\text { (STERR) }\end{array}$ & $\begin{array}{c}\text { T Statistics } \\
\text { (|O/STERR|) }\end{array}$ \\
\hline $\begin{array}{c}\text { Aktivitas Browsing -> } \\
\text { Flow }\end{array}$ & 0.897273 & 0.893101 & 0.025496 & 0.025496 & 35.193116 \\
$\begin{array}{c}\text { Aktivitas Browsing -> } \\
\text { Kepercayaan Online }\end{array}$ & 0.897213 & 0.893783 & 0.023473 & 0.023473 & 38.223738 \\
$\begin{array}{c}\text { Aktivitas Browsing -> } \\
\text { Niat Pembelian }\end{array}$ & 0.878497 & 0.876027 & 0.025382 & 0.025382 & 34.610899 \\
$\begin{array}{c}\text { Flow -> Niat Pembelian } \\
\text { Kepercayaan Online -> } \\
\text { Flow }\end{array}$ & 0.392479 & 0.382158 & 0.076154 & 0.076154 & 5.153756 \\
$\begin{array}{c}\text { Kepercayaan Online -> } \\
\text { Niat Pembelian }\end{array}$ & 0.540454 & 0.544196 & 0.059573 & 0.059573 & 9.072122 \\
\hline
\end{tabular}


Berdasarkan hasil pengolahan data yang dilakukan, diperoleh hasil bahwa terdapat pengaruh positif kepecayaan online terhadap kondisi flow pada kedua kategori produk involvement. Dalam hal perilaku konsumen di ranah online, faktor kepercayaan terhadap virtual store yang dalam hal ini adalah akun Instagram merupakan hal utama karena konsumen lebih dominan dihadapkan pada aktivitas yang berhubungan dengan stimuli visual yang berhubungan dengan display berupa posting barang-barang terbaru di akun Instagram, pemilihan kata-kata dalam komunikasi pemasaran dan juga komitmen untuk memenuhi semua kampanye pemasaran mereka. Ketika suatu akun Instagram dengan segala strategi komunikasi pemasarannya dapat membuat konsumen memiliki kepercayaan pada akun tersebut, maka konsumen tidak segan memberikan perhatian dan fokus pada saat menjelajahi akun tersebut dan kerapkali karena mereka menemukakn perasaan menyenangkan membuat mereka tanpa sadar telah menghabiskan banyak waktu pada aktifitasnya tersebut.

Berdasarkan hasil pengolahan data yang dilakukan, diperoleh hasil bahwa terdapat pengaruh yang signifikan antara aktifitas bowsing terhadap niat pembelian produk terbaru di Instagram pada kedua kategori produk involvement, Analogi yang dapat dijelaskan disini adalah tujuan konsumen melakukan penjelajahan online meliputi beberpa motif, diantaranya ada yang melakukannya untuk motif rekreasional dan eksploratori untuk killing time, ada juga yang memang sengaja melakukan aktifitas tersebut untuk mencari informasi dan update barang terbaru di Insagram.

Berdasarkan hasil pengolahan data yang dilakukan, diperoleh hasil bahwa terdapat pengaruh positif antara kondisi flow terhadap niat pembelian pada kedua kategori produk involvement. Kondisi flow membuat perhatian konsumen terfokus saat melakukan aktifitas menjelajahi akun Instagram yang mereka ikuti. Dari aktifitas tersebut, mereka akan merasakan perasaan yang menyenangkan akibat terpapar komunikasi pemasaran melalui pengalaman audio-visual yang disajikan oleh pemasar. Excellence experience yang dirasakan konsumen hingga konsumen kadangkala lupa waktu membuat konsumen dengan senang hati revisit akun tersebut. imbas dari akttifitas ini akan memunculkan suatu dorongan niat pembelian dari dalam diri konsumen.

Berdasarkan hasil pengolahan data yang dilakukan, diperoleh hasil bahwa terdapat pengaruh positif antara kepercayaan online pada produk terbaru di Instagram pada kedua kategori produk involvement yang pengguna ikuti terhadap niat pembelian. Semakin konsumen percaya dengan suatu akun di Instagram, maka tidak ada denial atau penolakan tentang informasi di akun tersebut. Informasi, promosi, dan spesifikasi yang dipaparkan mendapatkan perhatian konsumen, karena apabila konsumen telah percaya pada suatu akun, maka mereka akan engaged dengan akun tersebut dan dimasa depan mereka tidak aka nada perasaan ragu untuk melakukan transaksi dengan akun tersebut. Apabila mereka membutuhkan suatu produk, dan akun tersebut menawarkan produk sesuai dengan ekpektasi mereka, akan muncul niat dari dalam diri mereka untuk melakukan pembelian barang di akun tersebut.

\section{SIMPULAN}

Berdasarkan hasil yang didapat menunjukkan bahwa aktivitas browsing pada Instagram baik untuk kategori High maupun Low Involvement produk memiliki pengaruh positif terhadap kondisi flow, kepercayaan online, dan niat pembelian. Kemudian kepercayaan 
online pada akun di Instagram memiliki pengaruh positif terhadap kondisi flow. Demikian juga dengan variabel kondisi flow dan kepercayaan online juga memiliki pengaruh terhadap niat pembelian barang-barang terbaru di Instagram. Tidak ada perbedaan perilaku konsumen terhadap niat pembelian di ranah online antara High maupun Low Involvement produk.

Secara ilmu pengetahuan, penelitian ini dapat memberikan tambahan referensi bagi akademisi mengenai aktifitas browsing pada ranah online melalui media sosial Instagram dapat memberikan pengaruh terhadap kondisi flow dan kepercayaan online, dan kemudian ketiga variabel tersebut memberikan dampak terhadap munculnya niat pembelian pada barang-barang terbaru yang di posting Instagram. Hasil tersebut tidak hanya diperlihatkan pada penelitian-penelitian terdahulu yang biasanya dilakukan pada personal computer dan laptop , pada saat sekarang ini dimana semuanya serba dapat dilakukan dengan mobile karena adanya peningkatan kualitas koneksi internet dan semakin populernya belanja menggunakan gadget. Maka niat pembelian juga dapat muncul pada saat konsumen melakukan penjelajahan online memakai perangkat smartphone dengan berbagai macam alasan praktis dan benefitnya.

Penelitian ini memberikan kontribusi yang baik bagi para internet marketer dan pemilik akun di Instagram bagaimana dia mendesain strategi kampanya pemasaran mereka sehingga mereka dapat mengintegrasikan segala resource yang mereka miliki untuk memaksimalkan potensi Instagram sebagai salah satu tools pemasaran mereka.

Pada hasil penelitian ini menguraikan bagaimana aktifitas browsing yang dilakukan konsumen pada suatu akun di Instagram untuk mencari informasi dan melihat spesifikasi tentang barang-barang baru yang di posting oleh suatu akun d Instagram dimediasi oleh variabel yakni kondisi flow dan kepercayaan online dapat mempengaruhi munculnya niat pembelian barang-barang tersebut dari dalam diri konsumen. Hal ini memberikan petunjuk kepada para pemasar dalam ranah online yang memanfaatkan media sosial Instagram dalam kampanye pemasaran mereka untuk lebih jeli bagaimana merangsang munculnya niat pembelian dari dalam diri konsumen.

Instagram sebagai media sosial yang popular dan potensial dalam aktifitas pemasaran menawarkan tools untuk memanjakan audio-visual bagi pengguna Instagram yang mengaksesnya. Pemilihan caption tiap posting foto, video dan pemilihan kata-kata untuk memberikan informasi harus diperhatikan dengan baik sehingga dapat mempersuasi pengguna Instagram agar mempunyai persepsi positif terhadap barang atau brand yang mereka miliki.

Dalam dunia yang semakin mobile , dimana segalanya bisa diakses dalam satu genggaman, menumbuhkan kepercayaan online dengan menjaga komitmen baik ketepatan informasi yang diberikan dan juga bagaimana memenuhi semua yang dijanjikan merupakan syarat mutlak. Karena apabila konsumen sudah memiliki kepercayaan terhadap suatu perusahaan yang di wakili oleh akun di Instagram, maka akan semakin mudah pula menstimuli munculnya niat pembelian mereka.

Pada penelitian ini, barang yang di uji dikelompokkan berdasarkan tingkat involvement nya, dengan hasil pengumpulan datanya di analisis secara general dengan cakupan hanya di 3 kota yaitu Surabaya, Gresik, dan Sidoarjo. Di penelitian selanjutnya mungkin bisa juga menguji kategori barang yang lain dengan meneliti perbedaan preferensi gender pada perilaku konsumen mereka dengan cakupan wilayah yang lebih luas. 
Pada penelitian ini, pengumpulan data dilakukan secara offline dengan membagikan kuesioner secara langsung kepada para responden, mungkin di penelitian selanjutnya pengumpulan data bisa dilakukan secara online sehingga cakupan wilayah lebih luas dengan jumlah responden yang lebih besar.

\section{REFERENCES}

Adam Rapp, Lauren Skinner Bietel Spacher, Dhruv Grewal, Douglas E Hughes. (2013). Understanding Social Media Effect Across Seller, Retailer, and Consumer Interactions. Journal of the Academic Marketing Science. No 41:576-566

Arnold Kamis, Tziporah Stern, Daniel M.Ladik. (2010). A Flow-based Model of Websites Intentions when Users Customize Products in Business-to-Cunsomer Electronic Commerce. Journal of Inf Syst Front. DOI 10.1007

Burns, A. C., \& Bush, R. (2014). Marketing Research: Seventh Edition. Harlow, Edinburg Gate: Pearson Education Limited.

Chang, M. K., Cheung, W., \& Lai, V. S. (2005). Literature derived reference models for the adoption of online shoping. Information and Management, 42, 543-559.

Chang, M. K., Cheung, W., \& Tang, M. (2013). Building trust online: Interactions among trust building mechanisms. Information \& Management, 50, 439-445.

Charlas Mathwick and Edward Rigdon. (2004). Play, Flow, and the Online Search Experience. Journal of Consumer Research. Vol 31.

Chia-Lin Hsu, Kuo-Chieng Chang, Mu-Chen Chen. (2012). The Impact of Website Quality on Customer Satisfaction and Purchase Intention : Perceived Playfulness and Perceived Flow as Mediators. Journal of Information System E-Business Managerial. No.10:549-570

Chia-Lin Hsu, Kuo-Chieng Chang, Mu-Chen Chen. (2012). Flow Experience and Internet Shopping Behaviour: Investigating the Moderating Effect of Customer Characteristic. Journal of System Research and Behavioral Science.No.317-332

Chia-Lin Hsu, Kuo-Chien Chang, Nien-Te Kuo, Yi-Sung Cheng. (2016). ResearchThe Mediating Affect of Flow Experience on Social Shopping Behaviour. DOI:10.1177

Ghozali, I. (2014). Structural Equation Modeling: Metode Alternatif Dengan Partial Least Squares (PLS). Semarang: Badan Penerbit Universitas Diponegoro Semarang.

Hair, J. F., Black, W. C., Babin, B. J., \& Anderson, R. E. (2010). Multivariate Data Analysis: A Global Perspective, Seventh Edition. New Jersey: Pearson Education, Inc.

Hawkins, D. I., \& Mothersbaugh, D. L. (2013). Consumer Behavior: Building Marketing Strategy. New York: McGraw-Hill.

Huang, Ming-Hui (2006), "Flow, Enduring, and Situational Involvement in the Web Environment:ATripartite Second-order Examination," Psychology and Marketing, 23 (5), 383-411.

Huang, E. (2012). Online experience and virtual goods purchase intention. Internet Research, 22(3), 252-274.

Huang, L. T. (2015) . Flow and social capital theory in online impulse buying. Journal of Business Research, 69(6), 2277-2283. 
Hsu, C. L., Chang, K. C., \& Chen, M. C. (2012). Flow Experience and Internet Shopping Behavior: Investigating the Moderating Effect of Consumer Characteristics. System Research and Behavioral Science, 29, 317-332.

Ibnu Subiyanto. (2000). Metodologi Penelitian. Yogyakarta: UPP AMP YKPN.

Jacoby, J. (2002). Stimulus-Organism-Response Reconsidered: An Evolutionary Step in Modeling (Consumer) Behavior. Journal of Consumer Psychology, 12(1), 51-57.

Jas Raj Bohra and Mallika Bishnoi. (2016). Instagram : The New Edge of Online Retailing. World Journal of Research and Review. Vol 3. Pages 43-46.

Jessica Wongso Putri. (2015). Factors Affecting Customers Online Search Intention and Online Purchase Intention using Social Networks: Case Study of Online Shop on Instagram , iBuss Management Vol. 3, No. 2, 232-240

John L.Sherry. Flow and Media Enjoyment. (2004). Communication Theory. Pages 328-347

Koufaris, M. (2002). Applying the Technology Acceptance Model and Flow Theory to Online Consumer Behavior. Information System research, 13(2), 205-223.

Koufaris, M., \& Sosa, W. H. (2004). The development of initial trust in an online company by new customers. Informtion \& Management, 41, 377-397.

Koufaris, M., Kambil, A., \& Labarbera, P. A. (2001). Consumer Behavior in Web-Based Commerce: An Empirical Study. International Journal of Electronic Commerce, 6(2), 115-138.

Kun Song and Ann Marie Fiore. (2007). Telepresence and Fantasy in Online Appareal Shopping Experience.Journal of Fashion Marketing and Management. Vol.11 No.4 2007

Lin, J., \& Chuan, C. H. (2014). A Study on Youth Online Impulse Purchase: The Relationship between Individual Difference, Shopping Enjoyment, Emotion Response and Purchase. Journal of Creative Communication, 8(2\&3), 209-229.

Novak, Thomas P., Donna L. Hoffman and Yiu-Fai Yung. (2000). Measuring the Customer Experience in Online Environments: A Structural Modeling Approach. Marketing Science, 19 (1), 22-42.

Nuttamon Amornpashara. (2013). A study of the relationship between using Instagram and purchase intention.. J. Global Business Advancement, Vol. 8, No.3

Ono, A., Nakamura, A., Okuno, A., \& Sumikawa, M. (2012). Consumer Motivations in Browsing Online Stores with Mobile Devices. International Journal of Electronic Commerce. 16(4), 153-178.

Park, E. J., Kim, E. Y., Funches, V.M., \& Foxx, W. (2012). Apparel product attributes, web browsing, and e-impulse buying on shopping websites. Journal of Business Research, 65, 1583-1589.

Patrick Mikalef, Michael Gianakos, and Admantia Pateli. (2013). Shopping and Word of Mouth Intentions on Social Media. Journal of Theorotical and Applied Electronic Commerce Research. ISSN 0718-1876.

Rene Weber, Ron Tamborini, Amber Westcott=Barker, Benjamin Kantor. (2009). Theorizing Flow and Media Enjoyment as Cognitive Syncronization of Attentional and Rewards Networks.Communication Theory. 
Smith, D. N., \& Sivakumar, K. (2004). Flow and Internet shopping behavior: A conceptual model and research propositions. Journal of Business Research, 57, 1199-1208.

Sugiyono., \& Susanto, A. (2015). SPSS \& Risrel, Teori dan Aplikasi untuk Analisis Data Penelitian. Bandung: Penerbit Alfabeta.

Susan Rose. (2012). Online Customer Experience in e-Retailing: An empirical model of, Antecedents and Outcomes, Journal of Retailing 88 (2), 308-322.

Yakov Bart, Andrew T. Stephen, Miklos Sarvary. (2014). Which Product are Best Suited to Mobile Advertising? A Field Study of Mobile Display Advertising Effect on Cunsomer Attitudes and Intentions. Journal of Marketing Research. Vol L1, 270-285. 